\title{
Hashimoto's hypothyroidism presenting with SUFE (slipped upper femoral epiphysis)
}

\author{
Suma Uday, ${ }^{1}$ Brian Scott, ${ }^{2}$ Sabah Alvi ${ }^{1}$
}

${ }^{1}$ Department of Paediatric Endocrinology and Diabetes, Leeds Teaching Hospital, Leeds, UK

${ }^{2}$ Department of Paediatric Orthopaedic Surgery, Leeds Teaching Hospitals, Leeds, UK

\section{Correspondence to} Dr Sabah Alvi, sabah.alvi@leedsth.nhs.uk

Accepted 16 February 2014
CrossMark

To cite: Uday S, Scott B Alvi S. BMJ Case Rep Published online: [please include Day Month Year] doi:10.1136/bcr-2013203095

\section{DESCRIPTION}

A healthy 12-year-old girl presented to the emergency department with a 6 week history of atraumatic limp with left lower limb pain. An examination revealed limited range of movement at the left hip joint. Hip X-ray showed left slipped upper femoral epiphysis (SUFE) (figure 1), severity of which was assessed on CT scan.

Thyroid functions were performed preoperatively due to short stature (0.4th-2nd centile), overweight ( $>50$ th centile) and coarse facial features (figure 2). Results confirmed autoimmune (Hashimoto's) hypothyroidism with thyroid stimulating hormone $(\mathrm{TSH})>300 \mathrm{mIU} / \mathrm{L}(0.2-4)$, free thyroxine $2.6 \mathrm{pmol} / \mathrm{L}(10-25)$ and raised thyroid antibodies of $229 \mathrm{IU} / \mathrm{mL}(<100)$. Following referral to the paediatric endocrine team, a detailed history revealed static growth for 2 years, weight gain and tiredness. Bone age was delayed by 2 years, suggesting longstanding hypothyroidism.

She was started on levothyroxine, and open reduction and femoral neck osteotomy were deferred until TSH improved, due to the risk of postanaesthetic coma secondary to severe hypothyroidism. Clinical and biochemical euthyroidism was achieved by 4 weeks.

She attained menarche 3 weeks into treatment. A gonadotrophin-releasing hormone analogue was initiated to arrest puberty in an attempt to maximise height, as ovarian activity and increased growth from restoring euthyroidism result in rapid bone turnover and epiphysial fusion. ${ }^{1}$

SUFE has historically been linked with endocrinopathies, especially hypopituitarism and hypothyroidism. ${ }^{2}$ In around $30 \%$ of patients with SUFE the

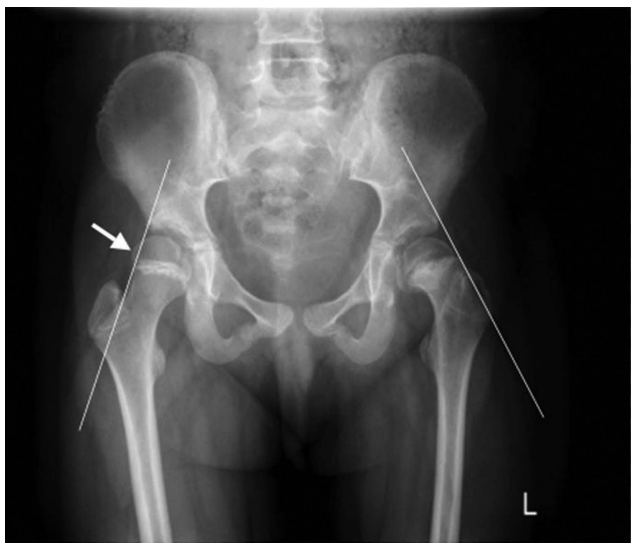

Figure 1 Kline's line (aka Trethowan's sign) is drawn along the femoral neck on an anterioposterior radiograph and should pass through the lateral margin of the femoral head (arrow). If the upper femoral epiphysis has slipped the line does not.

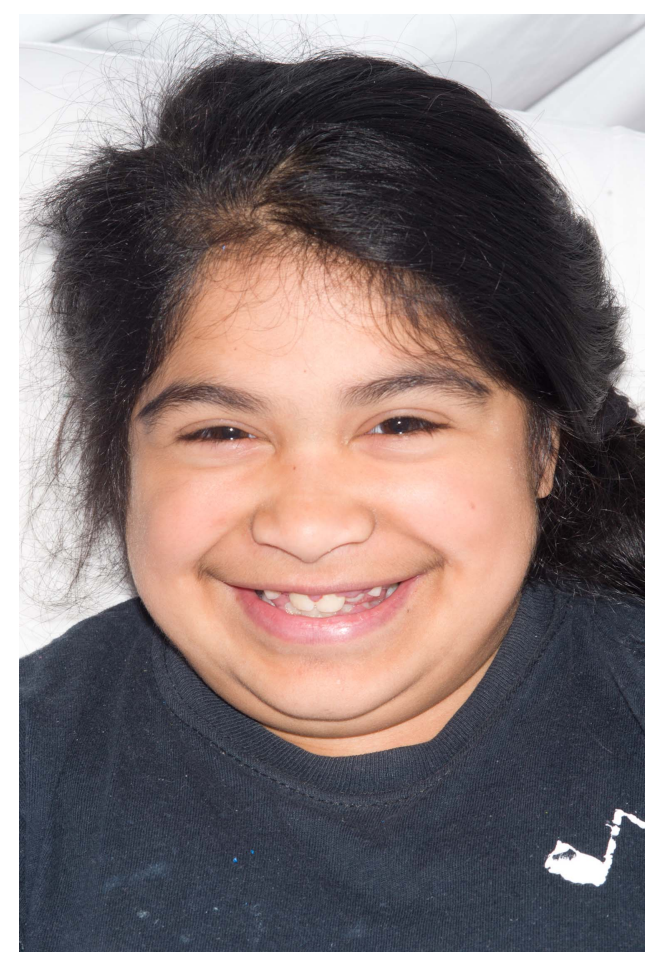

Figure 2 Coarse facial features suggestive of hypothyroidism.

contralateral hip also becomes involved over time and fixing the other hip prophylactically (figure 3 ) is often favoured. ${ }^{3}$ Uncertainty exists about future growth, as fixing the contralateral hip may result in leg length discrepancy due to epiphysiodesis effect.

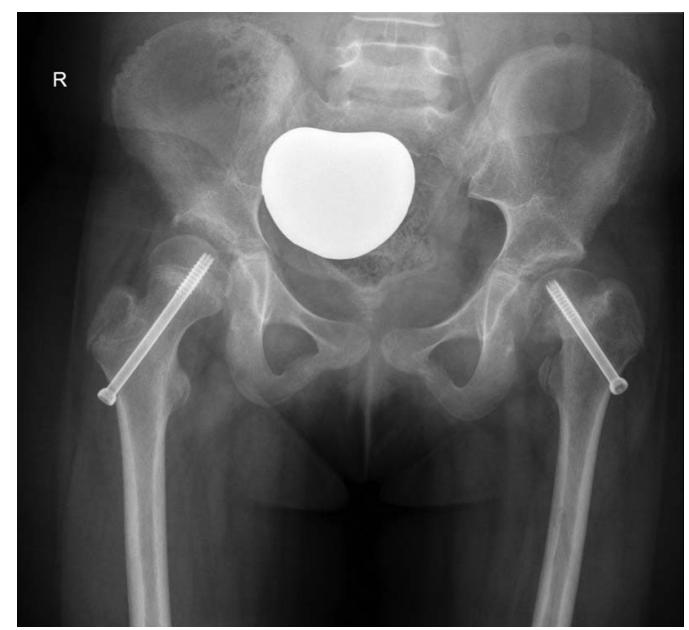

Figure 3 Postoperative film showing prophylactic fixation of right and slipped epiphysis fixation on left. 


\section{Learning points}

- It is important to consider hypothyroidism in a child with slipped upper femoral epiphysis (SUFE), who is short, obese or lethargic.

- Although moderate hypothyroidism causes delayed puberty, precocious or accelerated puberty is seen in severe hypothyroidism where thyroid stimulating hormone possibly acts as a gonadotrophin.

- It is important to be aware of the risk of SUFE in the contralateral hip and consider fixing this prophylactically.
Competing interests None.

Patient consent Obtained.

Provenance and peer review Not commissioned; externally peer reviewed.

\section{REFERENCES}

1 Cabrera SM, DiMeglio LA, Eugster EA. Incidence and characteristics of pseudoprecocious puberty because of severe primary hypothyroidism. J Pediatr 2013;162:637-9.

2 Puri R, Smith CS, Malhotra D, et al. Slipped upper femoral epiphysis and juvenile hypothyroidism. J Bone Joint Surg 1985;67:14-20.

3 Hansson G, Nathorst-Westfelt J. Management of the contralateral hip in patients with unilateral slipped upper femoral epiphysis. J Bone Joint Surg 2012;94:596-602.

Copyright 2014 BMJ Publishing Group. All rights reserved. For permission to reuse any of this content visit http://group.bmj.com/group/rights-licensing/permissions.

BMJ Case Report Fellows may re-use this article for personal use and teaching without any further permission.

Become a Fellow of BMJ Case Reports today and you can:

- Submit as many cases as you like

- Enjoy fast sympathetic peer review and rapid publication of accepted articles

- Access all the published articles

- Re-use any of the published material for personal use and teaching without further permission

For information on Institutional Fellowships contact consortiasales@bmjgroup.com

Visit casereports.bmj.com for more articles like this and to become a Fellow 